\title{
Paleoseismological Investigations at the Rurrand Fault, Lower Rhine Embayment
}

\author{
K. Lehmann ${ }^{1,2}$, J. Klostermann ${ }^{1}$ \& R. Pelzing ${ }^{1}$ \\ 1 Geological Survey of Northrhine-Westphalia, De-Greiff-Str. 195, D-47803 KREFELD, \\ Germany \\ 2 corresponding author; e-mail: klaus.lehmann@gd.nrw.de
}

Manuscript received: July 2000; accepted: April 2001

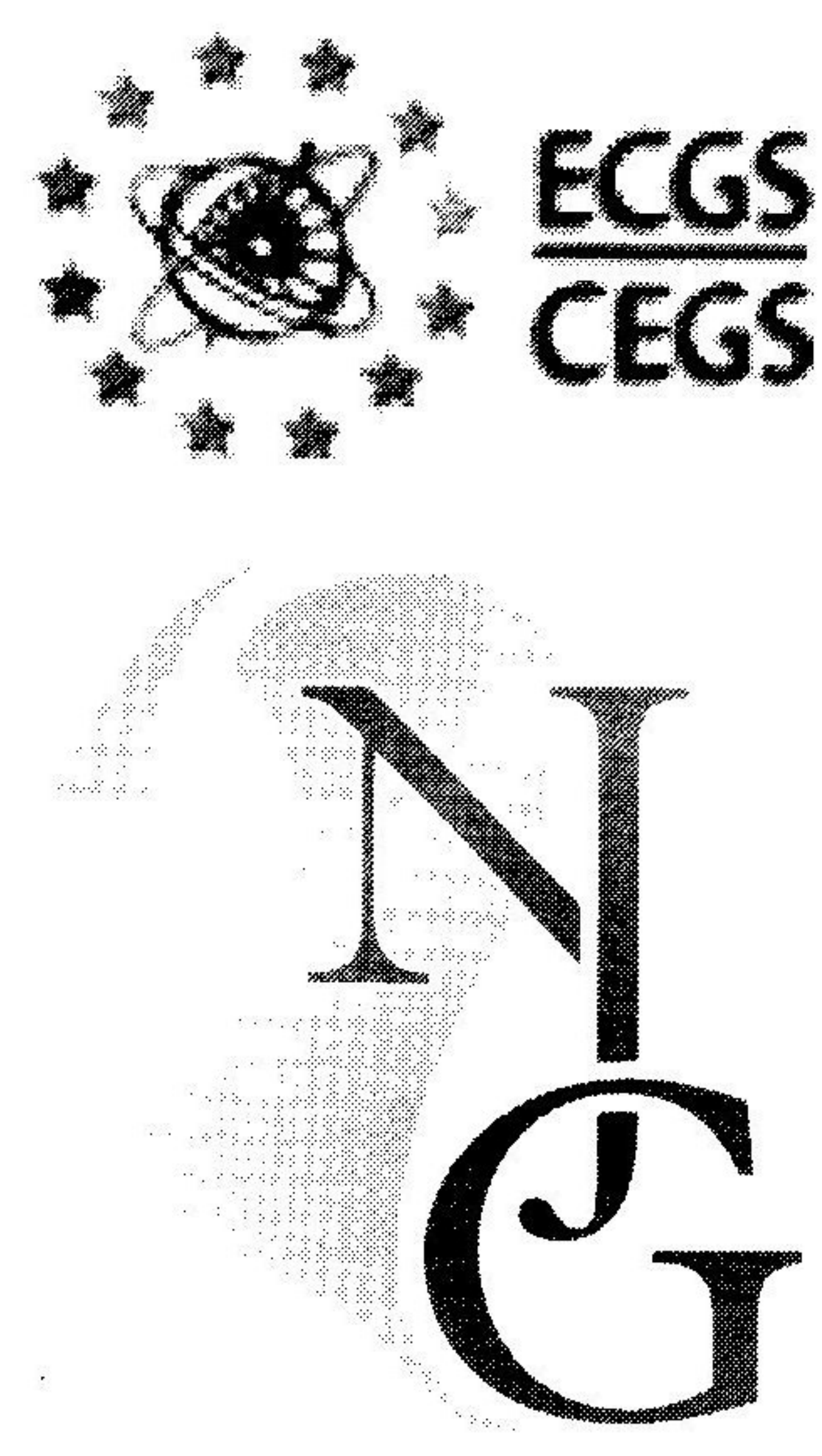

\begin{abstract}
From 1998 to 2000, we have studied the evidence for large paleoearthquakes at the Rurrand Fault. This fault represents the eastern border of the Roer Valley Graben, which is the tectonically most active region in the Lower Rhine Embayment. The purpose of our paleoseismological studies is to enlarge the seismicity data base for this region beyond instrumental records and historical reports using indications of surface-faulting events from stratigraphic conditions at active faults. Larger time spans considered in the earthquake catalogue will enable a more reliable statistical analysis which is required for seismic hazard assessment. Based on analyses of geological data and geomorphologic investigations, detailed geophysical surveying was carried out along the southern Rurrand Fault segment for the selection of a site appropriate to paleoseismological studies. Mapping of physical parameter contrasts with seismic reflection, VES, ERT, and GPR measurements along fault-crossing profiles inferred position and near-surface structure of the fault. At the site promising the best conditions, a trench was excavated across the fault near the city of Jülich, Germany. Within a depth of about $4 \mathrm{~m}$, the Rurrand Fault was exposed in an about $50 \mathrm{~m}$-wide system of faults and fault zones, affecting the stratigraphic sequence with various displacement characteristics and amounts of throw. According to heavy mineral analyses, the deposition time of most the exposed sediment strata was assigned to Pliocene and Lower Pleistocene time. These geological units are covered by loess layers deposited through solifluction processes during the Weichselian glacial, i.e. some tens of ka B.P., or - with lower probability - during the Saalian glacial. Several faults which had also affected the loess reflect younger fault activity. However, clear paleoseismic features were not observed in the trench, thus an unambiguous proof of the occurrence of coseismic fault displacements could not be furnished. Recently, differential subsidence due to drainage takes place in the surroundings of the nearby opencast mining. An amount of some $0.35 \mathrm{~m}$, concentrated in a very narrow lateral zone, has been observed during the last 40 a at about $1 \mathrm{~km}$ distance from the trench position. To date, the subsidence could not be clearly located in the trench exposure. Results from geodetic levelling campaigns will help to determine the offset residuals and to gain better insight into the ruling displacement processes at the Rurrand Fault.
\end{abstract}

Keywords: crustal deformation, normal faulting, paleoseismology, Roer Valley Graben

\section{Introduction}

As part of the western and central European rift system, the Lower Rhine Embayment (LRE) represents a tectonically active region (e.g. Ziegler, 1994). Extension of the upper crust in SW-NE direction (e.g. Ahorner, 1975; Van den Berg, 1994) induces subsidence of the LRE. The most recent phase of activity started in Oligocene time and is still ongoing (Herbst, 1958; Wrede \& Hilden, 1988; Zijerveld et al., 1992; Geluk et al., 1994). This process combined with the uplift of the Rhenish Shield caused the development of deep-reaching, NW-SE striking fault systems and fragmentation of the LRE into several blocks (e.g. Wrede \& Hilden, 1988). The region which has been affected by the highest amount of subsidence is the 
Roer Valley Graben (or Roer Graben) in the western part of the LRE (Ahorner, 1962; Van den Berg, 1994). The graben boundaries are formed by the Sandgewand -Feldbiss - Heerlerheide fault system in the SW and by the Peel-Roer Boundary Faults in the $\mathrm{NE}$ which are among the 'principle displacement zones' of the LRE (Van den Berg, 1994). A tectonic outline of the southern LRE is displayed in Fig. 1.

From analyses of age-altitude records of Pleistocene terraces in the south-west flank region of the Roer Valley Graben, van den Berg (1994) inferred episodically active crustal dynamics with an average uplift rate of $0.06 \mathrm{~mm} \mathrm{a}^{-1}$, but also for significant deviations from this value. Geological analysis of several drilling records in terms of tectonic subsidence curves ascertained the episodic and non-linear behaviour of the regional crustal activity (Zijerveld et al., 1992; Geluk et al., 1994). On the basis of data from Geluk et al. (1994), average subsidence rates were estimated to be in the order of $0.08 \mathrm{~mm} \mathrm{a}^{-1}$ during the Quaternary, and 0.15 to $0.3 \mathrm{~mm} \mathrm{a}^{-1}$ for the Late Pleistocene and Holocene (last 50 or 150 ka B.P., respectively; Camelbeeck \& Meghraoui, 1998). In contrast, geodetic measurements show much higher subsidence rates (e.g. Quitzow \& Vahlensieck, 1955; Van den Berg et al., 1994; Görres \& Campbell, 1998; Klostermann et al., 1998; Campbell et al., subm.). However, due to the short time interval of observation, they might represent a movement 'snapshot' which is probably not comparable with geologically determined long-term average rates. Additionally, recent local subsidence movements from massive mining-induced drainage have to be considered in the measurements of the last $40 \mathrm{a}$.

The mode of active tectonics, i.e. the question whether nonseismic (as stated e.g. by Ahorner, 1975, 1983), coseismic fault movements, or a combination of both lead to the observed long-term displacement rates, is recently under discussion (e.g. Meghraoui et al., 2000; Vanneste \& Verbeeck, 2001). Statistical seismicity analyses for the LRE may tackle this problem if earthquake records for sufficiently large time spans are considered. The first items in the catalogue of historical and instrumentally recorded earthquakes in the LRE go back only to 800 A.D. (Alexandre, 1994), based on studies by Sieberg (1940) and Sponheuer (1952). The strongest known earthquake in the Roer Valley Graben is the $M_{L} \approx 6.3$ Düren event which occurred in 1756 (Meidow, 1995). In order to enlarge the event data base into the past, paleoseismology may improve information in terms of geological records. Detailed studies at the Feldbiss fault zone resulted in evidence of earthquake-induced deformation with at least three large paleoearthquakes since probably 30000 a (Camelbeeck \& Meghraoui, 1996,

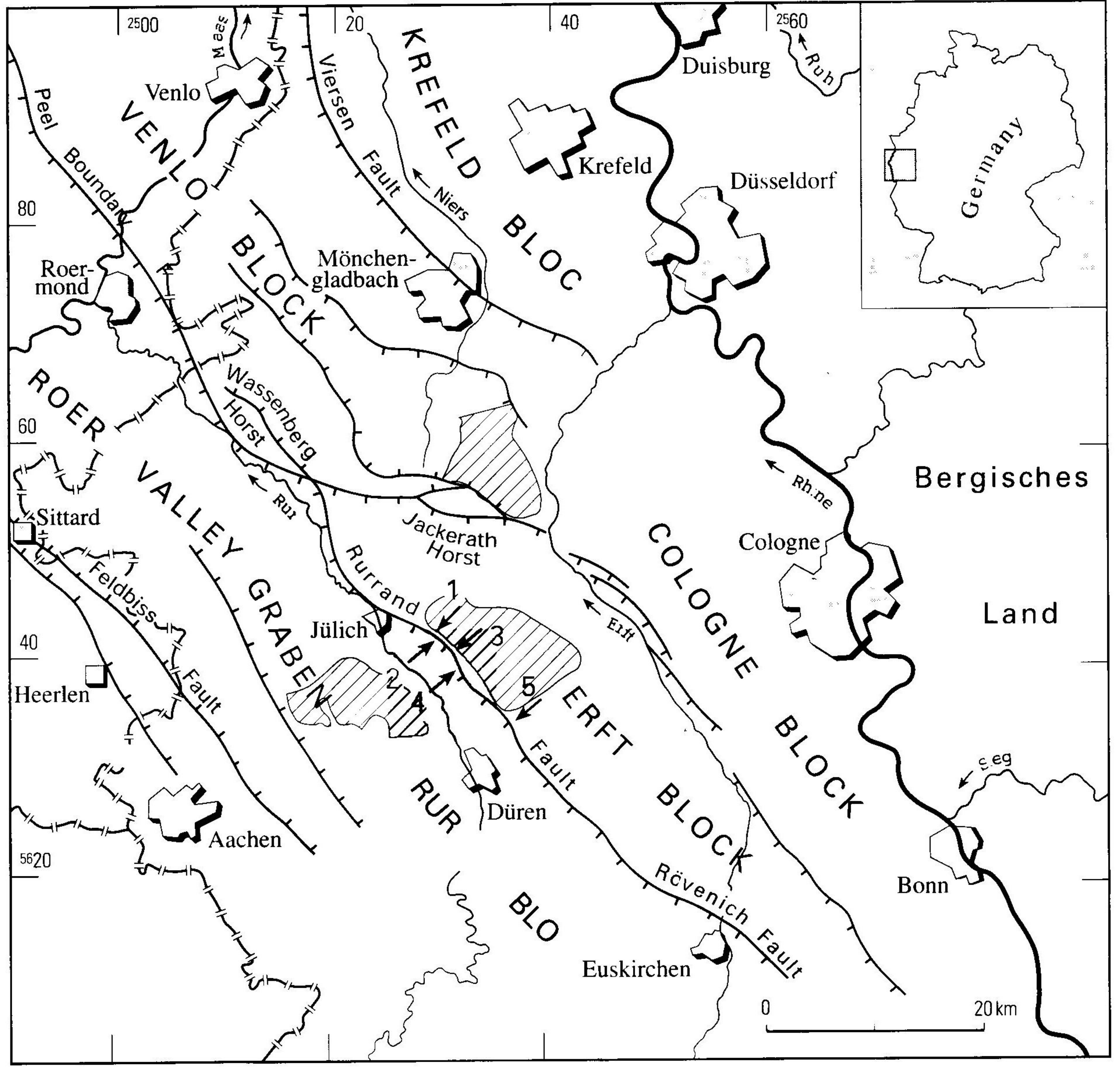

Fig. 1. Tectonic outline of the southern Lower Rhine Embayment (after Klostermann et al., 1998). Arrows show the sites of investigation at the Rurrand Fault section between the cities of Jülich and Düren (the numbering is according to the annotation in the text). Areas of active lignite mining are marked by hachures. 
1998; Vanneste et al., 1999; Meghraoui et al., 2000). The last surface-faulting event, dated between 610 and 880 A.D., was determined with a magnitude of $M_{\mathbb{W}}=6.3$. In this paper we report data from first paleoseismological investigations at the Rurrand (or Roer Boundary) Fault that were obtained during 1998 to 2000, complementing the observations at different faults in the LRE. Our goal was to extend the knowledge of the potential for the occurrence of large earthquakes in this region and - in the long term - to contribute to seismic hazard estimations. Preliminary results were published by Lehmann et al. (2001).

\section{Methodology}

In our paleoseismological studies at the Rurrand Fault we applied the multidisciplinary approach outlined by McCalpin (1996), considering geological and geomorphologic conditions, geophysical fault mapping and site investigations, as well as stratigraphic analyses during trenching. In the course of the PALEOSIS project (Commission of the European Communities, 2000), the methodology could be refined based on the project members' specific experiences. The application of corresponding methods and tools at several investigation sites in the Roer Valley Graben (cp. Demanet et al., 2001; Camelbeeck et al., 2001; Demanet et al., 2001; Van den Berg et al., 2001) ensured the comparability of investigation procedures.

The general geological conditions and the specific fault setting were assessed based on regional geological maps (Geologisches Landesamt Nordrhein-Westfalen,
1990) and available survey reports, borehole sections, etc. Geomorphologic studies contributed to the identification and mapping of active fault traces (reported by Hinzen et al., 2001). The presence of the fault along its assumed trace was verified through an older seismic section across the Rurrand Fault and a couple of profiles of vertical electrical sounding (VES) and ground penetrating radar (GPR). The seismic section showed evidence of the fault down to approximately $1 \mathrm{~km}$ through lateral changes in the subsurface structure. From VES profiling, the fault position could be inferred from a sudden change along the profiles in the specific electrical resistivity which can be followed down to some $100 \mathrm{~m}$, depending on the electrode spacing applied and on ground conditions (e.g. Vandenberghe, 1982). Through GPR measurements (reflection sounding profiling mode) with a $200 \mathrm{MHz}$ antenna, the fault structure was inferred with high spatial resolution down to some $4 \mathrm{~m}$ through lateral changes of the reflection pattern (e.g. Davis \& Annan, 1989; Cai et al., 1996). Fault evidence, position, and structure were investigated in more detail at a chosen test area by application of a set of geophysical near-surface survey techniques: shallow seismic reflection profiling, electrical resistivity tomography (ERT), and GPR profiling. In the electrode configuration used here, ERT allowed to follow the fault down to of approximately $25 \mathrm{~m}$ depth with a lateral resolution of some $2 \mathrm{~m}$ in terms of contrasts of the specific electrical resistivity (e.g. Loke \& Barker, 1996; Demanet et al., 2001a). The ranges of measurement resolution and penetration depth of the different methods used are compiled in Tab. 1.

Table 1. Explanatory notes to the geophysical survey methods applied in the investigations.

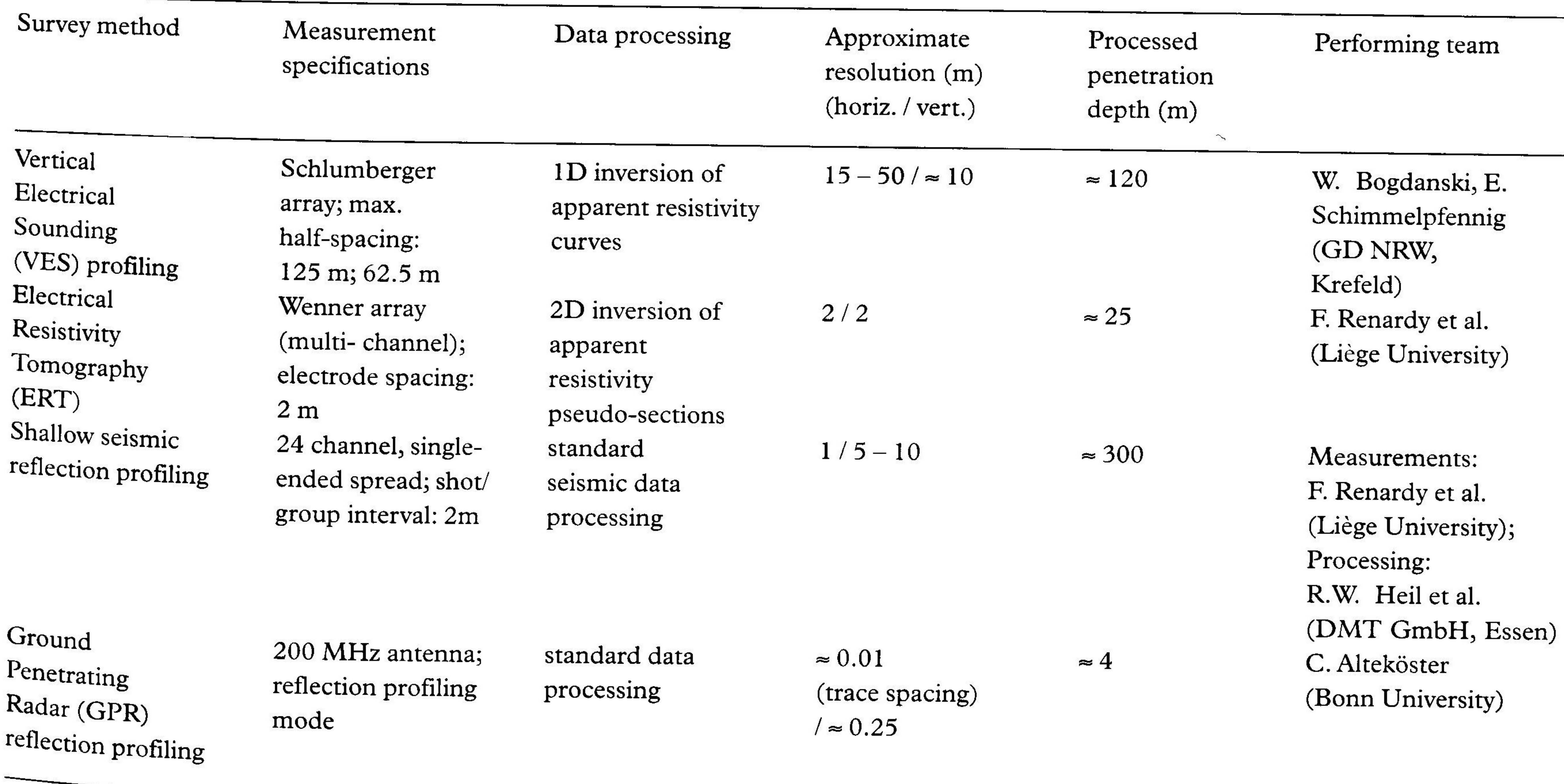


At that location where the preceding studies showed fault evidence within a feasible excavation depth, trenching was carried out on a fault-crossing profile. Detailed stratigraphic studies at the exposure and sample analyses - heavy mineral, pollen, optically stimulated luminescence (OSL; e.g. Forman et al., 1997) - of the corresponding geological units were used to interpret the fault's activity and to bracket ages of deformation. For this purpose, the trench wall was geologically mapped on a scale of 1:20. A wall segment was independently logged by Vanneste \& Verbeeck (2001). Further documentation was carried out through images corrected in perspective applying a recently developed digital imaging technique by Bonino (2001), through conventional photographs and, at selected parts, through lacquer peels. Trench data were extended to greater depths by GPR profiling on the trench floor.

\section{Site selection}

\section{General conditions}

In the selection of a suitable trench site, the target area had to be restricted beforehand due to several reasons: (1) Cities, villages, and roads spread over the target area, (2) numerous excavation and landfill sites, and (3) high ground water table in the alluvial terraces of the Rur river. Additionally, the plough zone in almost the entire region is reworked due to extensive agriculture.

\section{Fault setting}

The Rurrand Fault trends as the prolongation of the Rövenich Fault from SE of Düren up to the river Maas valley SE of Roermond, where it turns into the Peel Boundary Fault (s. Fig. 1; Geologisches Landesamt Nordrhein-Westfalen, 1990). It is expressed at the surface as a system of discontinuous fault segments, partly with en echelon character and branch zones (Ahorner, 1962; Klostermann, 1990). From fault plane solution of the $M_{L}=5.9$ Roermond earthquake, which occurred on the Peel Boundary Fault in 1992, a SW-dipping normal fault type was inferred (e.g. Pelzing, 1994). The main shock at a hypocentral depth of approximately $18 \mathrm{~km}$ triggered a number of aftershocks on the Rurrand Fault indicating connected fault segments.

Differential tectonic movements along the Rurrand Fault were investigated by Ahorner (1962) based on stratigraphic offsets: The throw of the Tertiary base along the Rurrand Fault increases from SE (some $100 \mathrm{~m}$ near Düren) towards the NW (some $600 \mathrm{~m} \mathrm{SE}$ of Jülich, and more than $1000 \mathrm{~m} \mathrm{~S}$ of the Wassenberg Horst; Klostermann, 1990). Regarding the Younger Main Terrace base, a throw of 40 to $50 \mathrm{~m}$ was determined. With detailed stratigraphic analyses of Quaternary sediments, Ahorner (1962) inferred a displacement rate of about $0.1 \mathrm{~mm} \mathrm{a}^{-1}$ and several phases with rates of roughly $1 \mathrm{~mm} \mathrm{a}^{-1}$. Digital elevation model analysis by Hinzen et al. (2001) showed a clear geomorphologic expression of the Rurrand Fault with height differences of some 8 to $12 \mathrm{~m}$ in the fault segment between Jülich and Düren. These studies ensure Quaternary fault activity, which is one of the essential preconditions for paleoseismological investigations.

Accelerated subsidence at the Rurrand Fault due to extensive drainage in the surroundings of the lignite opencast mining ( $E$ of the Rurrand Fault, near Jülich; s. Fig. 1) is evident since the 1960 s. Geodetic measurements on fault-crossing profiles document differential rates up to some $1 \mathrm{~cm} \mathrm{a}^{-1}$ between Jülich and Jülich-Stetternich in the time intervals 1997-1998 and 1998-1999 (Forschungszentrum Jülich $\mathrm{GmbH}$, 1999), and up to approximately $2 \mathrm{~cm} \mathrm{a}^{-1}$ during 1999-2000 (Forschungszentrum Jülich $\mathrm{GmbH}$, 2000). Considering data of older levelling campaigns, a 40 a - average rate of the same order can be deduced. The subsidence is expressed in a distinct scarplet on non-reworked grassland near the village of Stetternich, verified by geodetic levelling profiles with high point density (Rheinische Braunkohlenwerke AG, 2000) and observations of the field owner. Additionally, the development of fissures in the surface of nearby fault-crossing roads has been noticed.

\section{Geophysical investigations}

Considering the different aspects of site selection discussed above, we focused on the section of the Rurrand Fault between Jülich and Düren which is $13 \mathrm{~km}$ long. Geophysical surveying was applied to fault-perpendicular profiles at several sites along this fault section (Fig. 2; s. Fig. 1): (1) Jülich-Stetternich / Gut Wolfshoven; (2) Jülich-Stallbusch; (3) NiederzierHambach; (4) Niederzier; (5) Merzenich (from NW to SE). A reflection seismic section - available from archive material - crossing the assumed trace at site (3) evidences the Rurrand Fault down to some 1000 $\mathrm{m}$ depth by a SW-dipping discontinuity. VES profiling was carried out at sites (2), (4), and (5). Power lines, water pipes etc. in the immediate surroundings of the profile traces at sites (4) and (5) partly disturbed the measurement results. However, a clear lateral contrast in the specific resistivity was inferred at site (2), indicating the fault down to the depth of some $120 \mathrm{~m}$.

In order to resolve the fault's position with higher 


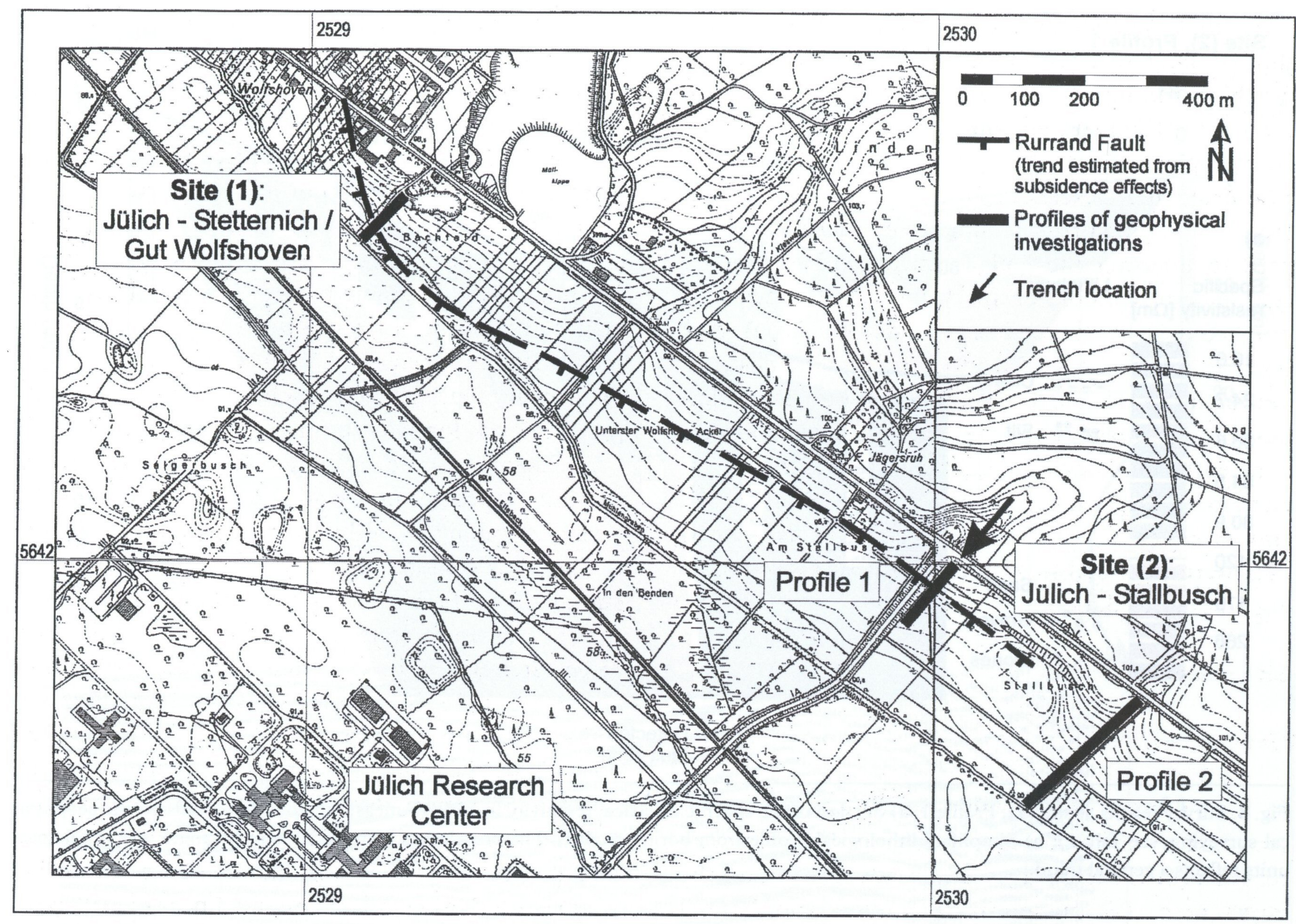

Fig. 2. Topographic map of a part of the investigation area, about $4 \mathrm{~km} \mathrm{E}$ of Jülich, including sites (1) and (2) (based on a topographic map 1:5000 with the Gauss-Krüger system used as grid reference; after Landesvermessungsamt Nordrhein-Westfalen, 1972). The trend of the Rurrand Fault (black dashed line) was roughly estimated from sites of known subsidence effects and can be correlated with an elevation gradient which is evident from the contour lines with $0.5 \mathrm{~m}$ resolution. The results of the geophysical survey profiles (black solid lines) are presented in Figs. 3, 4, and 5. The trench was excavated at site (2) along Profile 1 (arrow).

accuracy, additional surveying was acquired along two profiles at site (2) (Profile 1: NW, Profile 2: SE), which are $400 \mathrm{~m}$ apart (s. Fig. 2). On both profiles, ERT sections were derived from Wenner array measurements (Figs. 3a and 4a). Two laterally aligned sectors are relevant in both sections differing in two orders of resistivity. They were correlated to sandy (NE) and silty (SW) material, respectively. Within a spatial resolution of $2 \mathrm{~m}$, the corresponding transition zone is restricted to a quite sharp, steeply SW-dipping zone which is evident down to the observation depth, i.e. approximately $25 \mathrm{~m}$. This lateral contrast can be followed almost up to the surface at Profile 1, whereas it seems to be buried by a high-resistivity zone of a few metres thickness in the uppermost section of Profile 2.

A shallow seismic section along Profile 2 shows lateral changes in the reflector characteristics (Fig. 4b). The related SW-dipping discontinuities, evident within a lateral zone of at least $80 \mathrm{~m}$, can be interpreted as fault traces. The most prominent structure in the SW part corresponds to the position of the resistivity con- trast obtained by the ERT measurements. According to these results and considering the small distance between the Profiles 1 and 2, it is plausible to assign the electrical discontinuity at Profile 1 to the Rurrand Fault.

Highly resolved images of the shallow (i.e. down to a few meters) ground structure were revealed through GPR reflection profiling at the sites (1), (2), and (5). The Rurrand Fault is evident at each profile in a couple of discontinuities suggesting fault branching in the near-surface ground. The GPR sections of both profiles at site (2) clearly confirmed the fault trace, which was determined by electrical and seismic measurements. Several additional discontinuities were imaged within a zone of some $10 \mathrm{~m}$ towards the NE (Fig. 5b, c). As a result of geophysical surveying, appearance and characteristics of the Rurrand Fault were clearly improved at the site Jülich-Stallbusch (2). Within the range of a feasible trench depth, i.e. some $4 \mathrm{~m}$, the fault was reliably identified and located at Profile 1. 


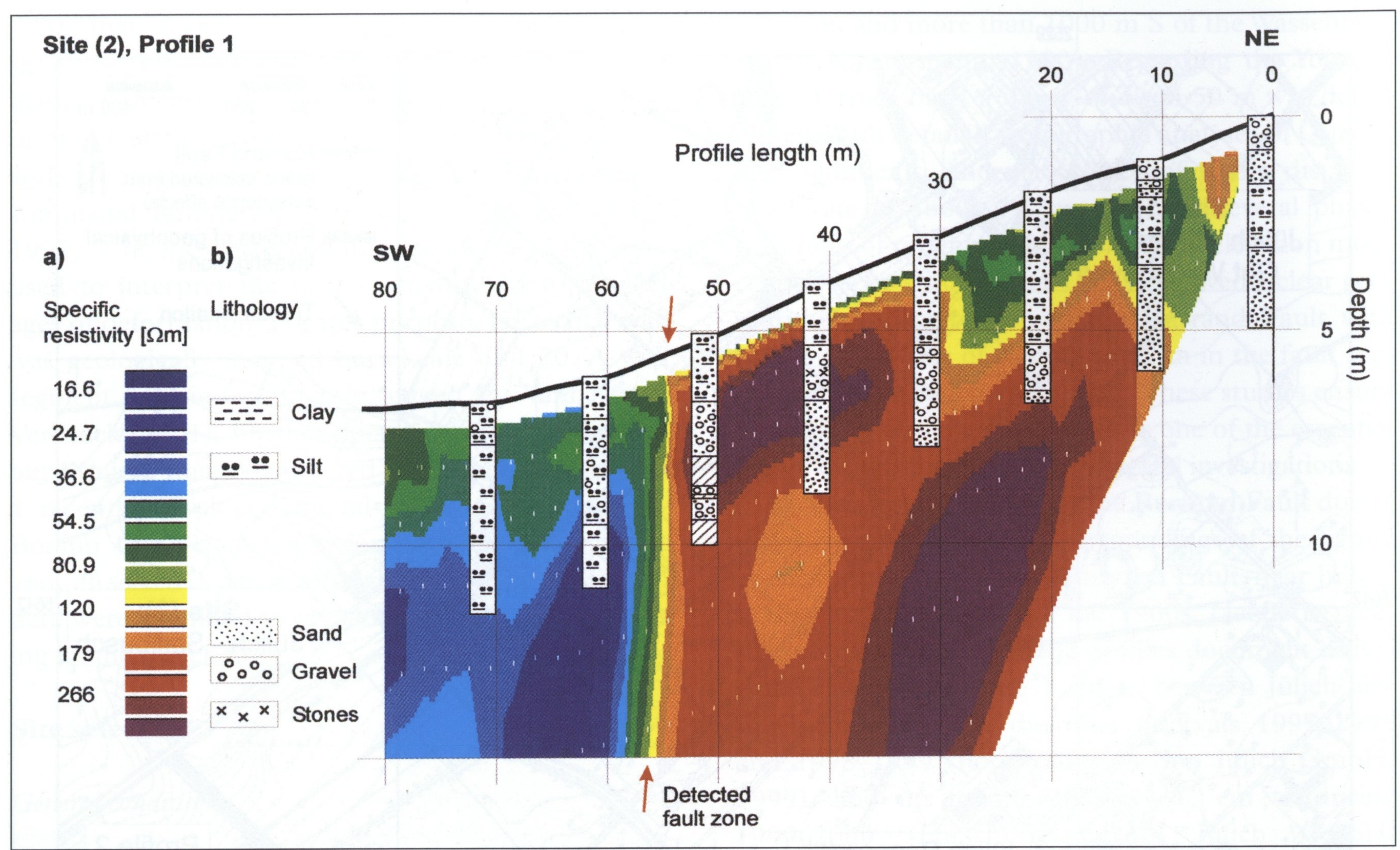

Fig. 3. Survey results at site (2), Profile 1: a) Section of the specific electrical resistivity from ERT measurements (for details on the geophysical surveying, see Tab. 1); b) Simplified lithological profile from boring records. The correlation between resistivity ranges and lithological units reflects a general trend.

On the fault segment investigated, clear indications of recently active differential subsidence are observed at site (1), approximately $1 \mathrm{~km} \mathrm{NW}$ of site (2), and at a fault-crossing road, situated some $15 \mathrm{~m} \mathrm{NW}$ of site (2), Profile 1, through fissures in the asphalt which are aligned with the fault's strike. Because the road was built on a man-made dam and founded on large concrete plates, the position of the fissures does not obviously indicate the fault. We compared the GPR sections obtained at the sites (1) and (2) (Fig. 5) in order to localise the activated fault. Within the zone of cracks detected at site (1), the fault trace which is affected by ongoing subsidence processes probably fits with the westernmost discontinuity. However, a preservation of the small-scale structure over a distance of approximately $1 \mathrm{~km}$ cannot be assumed with certainty. As a consequence, a direct correlation of the fault traces in both sections is vague. Thus, the position of subsidence at site (2) can not be determined on these measurements alone.

\section{Geological investigations}

Several fault-crossing geological sections obtained from drilling profiles were available, reaching down to Miocene sediments (Rheinische Braunkohlenwerke AG, 1987). At a section crossing the Rurrand
Fault about $160 \mathrm{~m} \mathrm{NW}$ of Profile 1 at site (2), the fault is evident with a throw of some $50 \mathrm{~m}$ at the base of the Younger Main Terrace. For the reconnaissance of the local fault expression at site (2), two parallel profiles of borings $(10 \mathrm{~m}$ apart) were drilled along Profile 1 , each with $10 \mathrm{~m}$ spacing. The corresponding lithology fits with the interpreted resistivity section (s. Fig. 3).

\section{Trenching}

\section{Trench construction}

Integrating all data from geological, geomorphic, and geophysical observations, site (2) Jülich-Stallbusch was chosen for trench operation (s. Fig. 2). The trench was excavated across the Rurrand Fault along Profile 1 with a length of about $60 \mathrm{~m}$ and a maximum depth of $4.3 \mathrm{~m}$. Due to shallow groundwater table, the observation depth was restricted to some $3 \mathrm{~m}$ in the deepest trench section. The SE wall was constructed with a benched, the NW wall with an about $60^{\circ}$ laid-back shape (Fig. 6), which provides optimum logging conditions. Additionally, shoring of the wall for stability and safety reasons was not required with this construction. 
Site (2), Profile 2

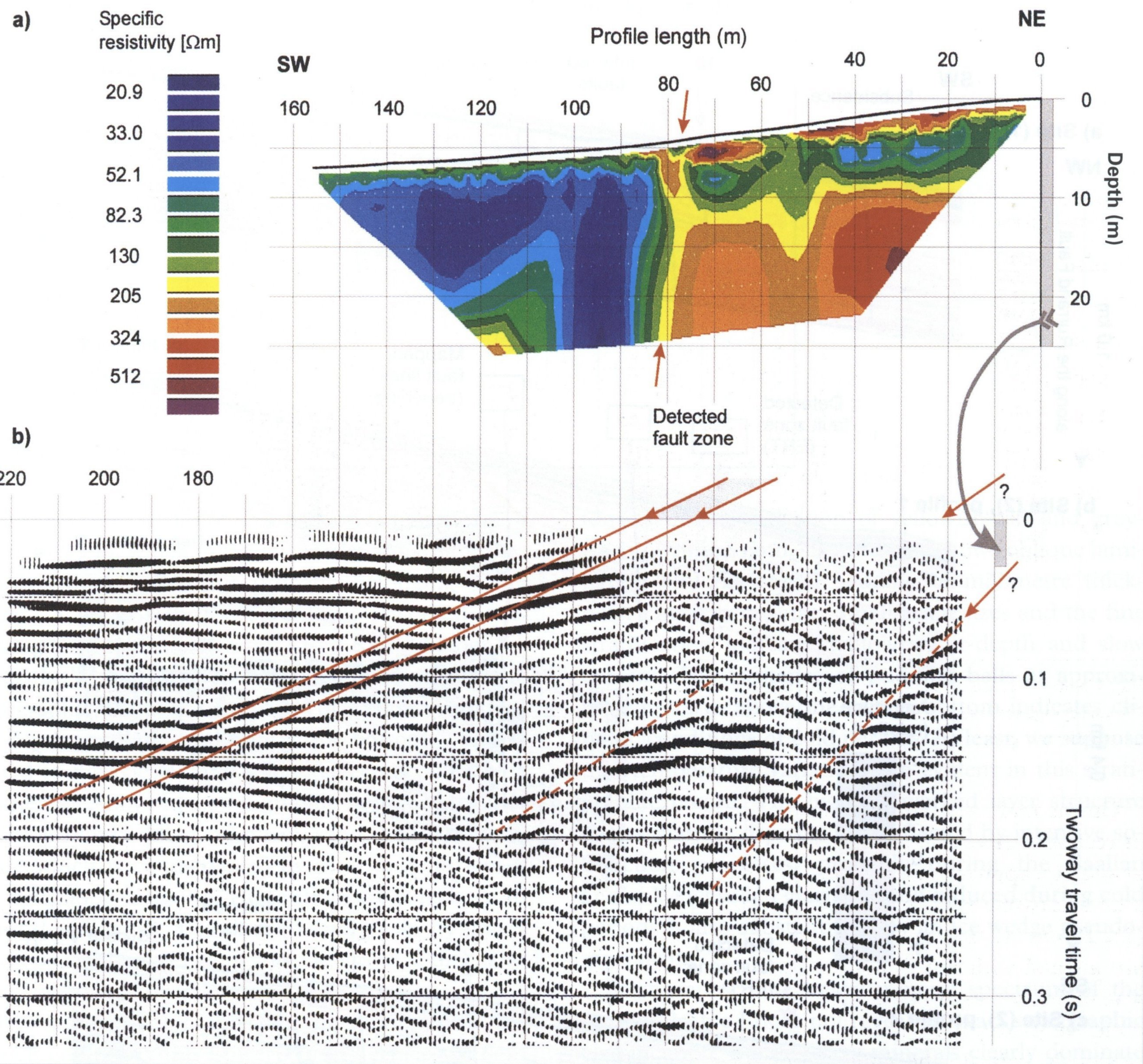

Fig. 4. Geophysical survey results at site (2), Profile 2: a) resistivity section from ERT analysis (after F. Renardy, LGIH, Liège University); b) seismic reflection section (after R.W. Heil et al., Deutsche Montan-Technologie GmbH, Essen). Positions of inferred faults are denoted by arrows. The shaded bars at the right mark comparable depths in both sections.

\section{Stratigraphic sequence}

The stratigraphy exposed in the trench is structured by several tectonic fault lines (Fig. 7): a system of four faults $(\mathrm{F} 1-\mathrm{F} 4)$ in the western part and, probably, a major fault (F0) in the eastern part of the trench. Additionally, a complex fault zone (FZ5) was observed in the westernmost part of the trench. The existence of fault F6 which is furthest to the W could not be reliably verified. The continuation of F2 into greater depths was followed by GPR profiling on the trench floor (s. Fig. 5b). All stratigraphic classifications given in the following section are based on heavy mineral analyses and on the interpretation of specific features evident in the sediments. According to these results most the stratigraphic units in the trench were assigned to Pliocene and Lower Pleistocene time (Fig. 8). Dating of loess samples through pollen analysis was not successful. OSL dating of the loess units failed with most samples. From three samples sedimentation ages were determined within large ranges of uncertainties: $(67.3 \pm 13.4)$ ka B.P. (lower portion of the loess unit W of F0), $(43.4 \pm 12.6) \mathrm{ka}$ B.P. (loess unit between F3 and F4), $(4.7 \pm 1.0) \mathrm{ka}$ B.P. (colluvium in the upper portion of the trench, at FZ5). These results are in agreement with the stratigraphic interpretation. 


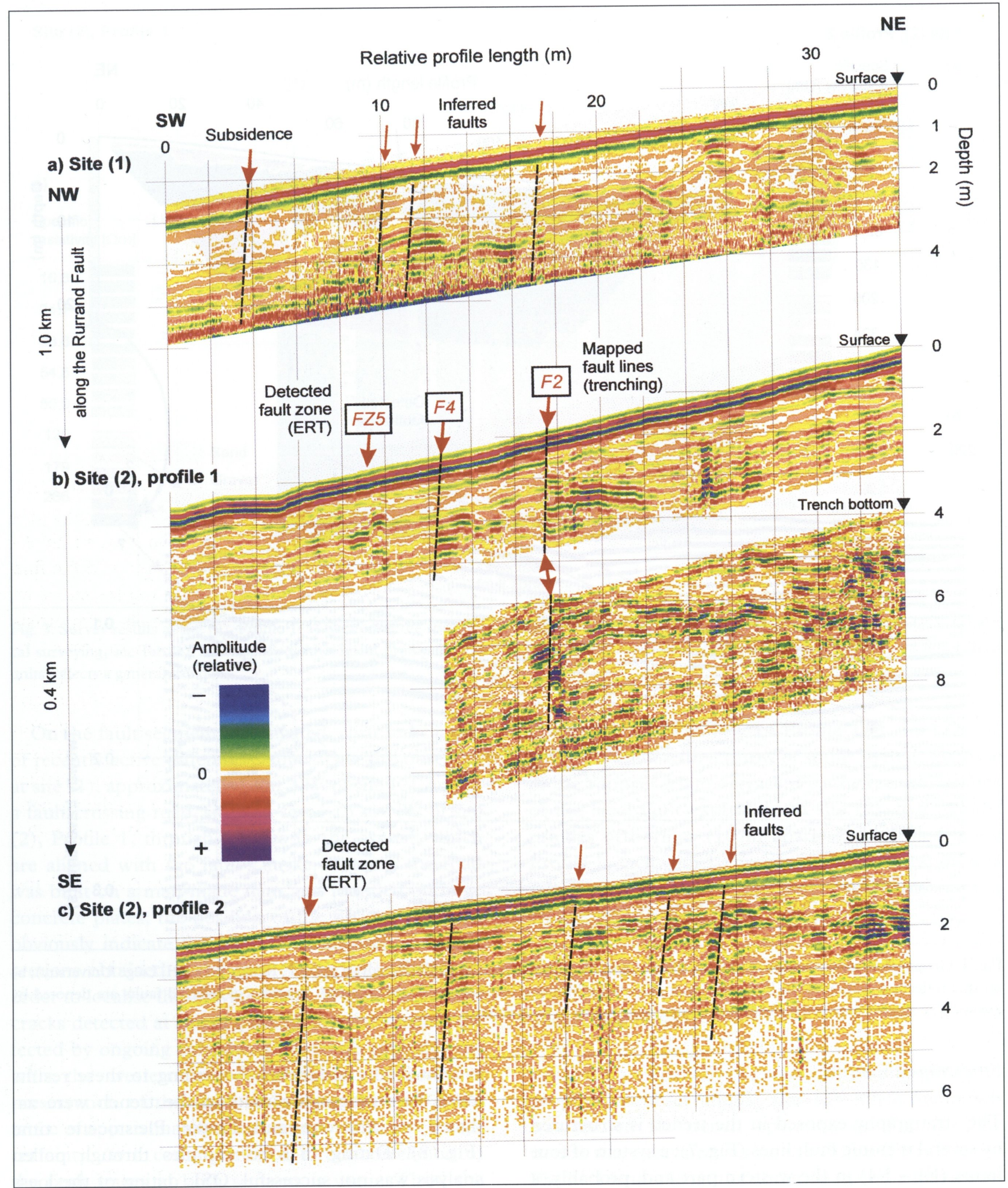

Fig. 5. Geophysical survey results from $200 \mathrm{MHz}$ GPR measurements at several sites across the Rurrand Fault with inferred faults: a) Site (1) Stetternich / Gut Wolfshoven; b) Site (2) Jülich-Stallbusch, Profile 1; c) Site (2), Profile 2 (after C. Alteköster, Geological Institute, Bonn University). Positions of inferred faults are denoted by arrows.

\section{Overview}

In the eastern part of the trench, reddish-yellow fine sand is exposed, covered by interbeddings of silt and sand. These strata are intensively reworked by solifluction. The sequence is intersected probably by an ice wedge pseudomorphism in the easternmost part. On account of heavy mineral analyses, the entire sequence has to be assigned to Pliocene time. The solifluction processes should have been active during the Saalian and/or Weichselian glacial. 


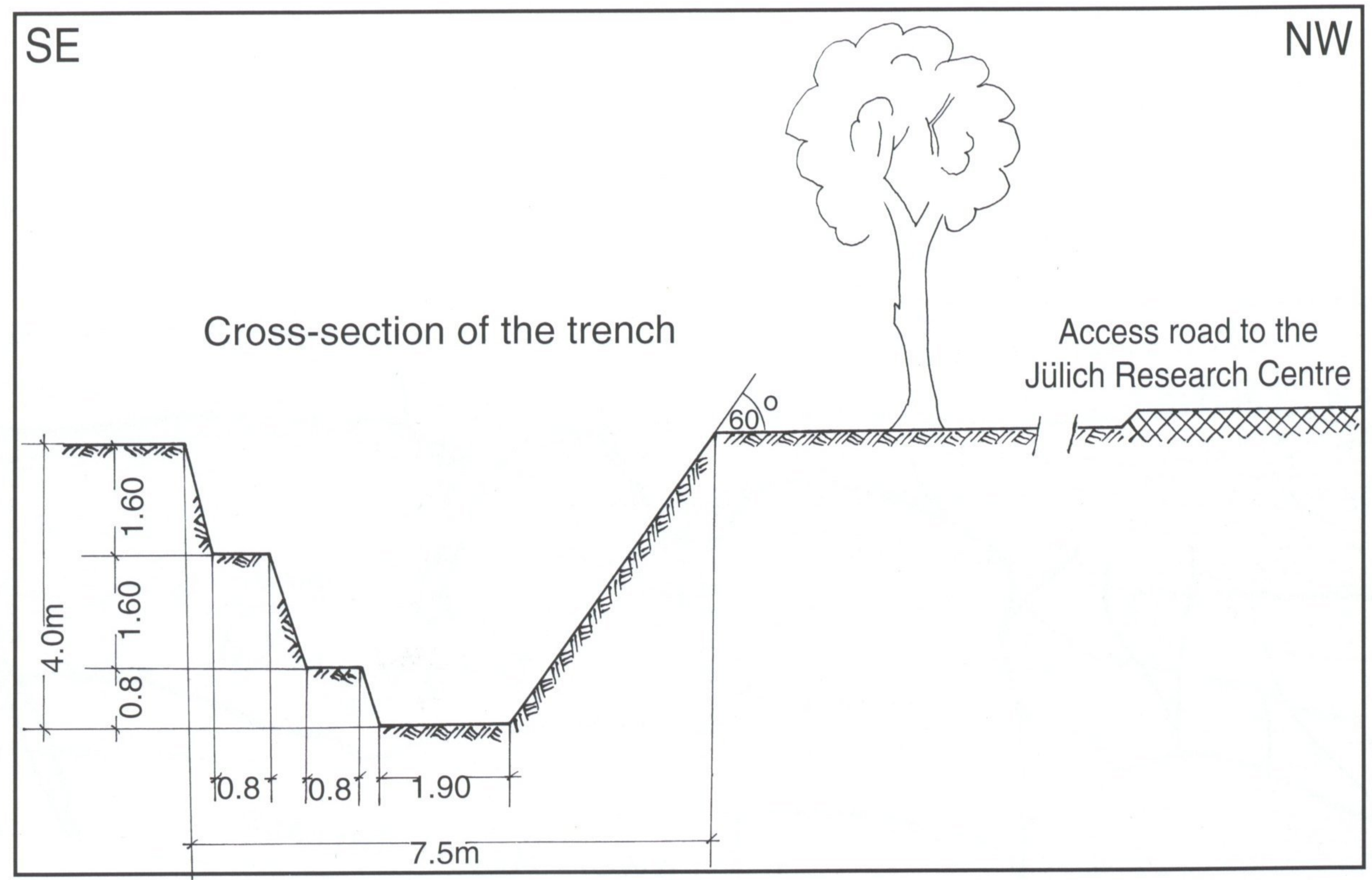

Fig. 6. Construction of the JülichStallbusch trench (cross-section).

Towards the $\mathrm{W}$ follows a section exposed on a length of $13 \mathrm{~m}$, which in the lower trench part consists of a $2 \mathrm{~m}$-thick gravel unit, probably belonging to the gravel ('Schotter') d. It is covered by reworked loess sediments with a thickness of 2 to $2.8 \mathrm{~m}$. Further towards the $\mathrm{W}$ and up to fault $\mathrm{F} 2$, the lower unit of the stratigraphic sequence consists of yellow coloured fine-sandy medium sand right at the bottom, which is related to the Kieseloolith layers (siliceous oolite type sediments). Above it, a stratigraphic unit consisting of intensive interbedding of gravel, sand, and silt is exposed which is characterised by sand and silt lenses and by chaotic structure. These strata are correlated to gravel $\mathrm{d}$ sediments. They are covered again by gravel which probably also belongs to the gravel $\mathrm{d}$ unit, and by the overlying reworked loess.

Between faults F2 and F4, the stratigraphic sequence comprises the Lower Hösel Terrace overlain by gravel $\mathrm{d}$ sediments. A unit of reworked loess on top of these terrace bodies exposes an ice wedge pseudomorphism reaching down to the gravel $\mathrm{d}$. W of $\mathrm{F} 4$, the fault zone FZ5 intersects the sequence. Due to the complex structure which is present in these layers, recently active intensive landslide processes are evident.

\section{Pliocene (not classified)}

Petrography and genesis: Pliocene deposits are exposed in the easternmost trench section. They consist in the lower part of reddish-yellow medium-sandy fine sand with gravelly intercalations. This $1.2 \mathrm{~m}$ thick section of the stratigraphic sequence is characterised in numerous parts by climbing ripple marks (Fig. 9). They indicate fluviatile run-off channels with constant flow velocity. Additionally, oblique lamination with a thickness of up to $10 \mathrm{~cm}$ ensure the fluviatile character of the sediments. In the hangingwall, an in- tensive interstratification of yellowish-red and greyish-brown fine sand, silt, and clay shows oblique lamination and horizontal bedding of millimetre thickness. The extraordinary small grain sizes and the fine stratification indicate shallow water-depth and slow current. The existence of pudding balls at approximately $1.8 \mathrm{~m}$ above the trench bottom indicates climatic conditions of cold periods. At least, we suppose that temperature variations are evident in this stratigraphic record. The highly reworked layer structure shows that the deposits were affected by intensive solifluction processes, probably during the Saalian and/or Weichselian glacial. Strain induced during cold periods is also substantiated by an ice wedge pseudomorphism.

Stratigraphy: The heavy mineral spectrum of the sample Profile I does not reveal an exact stratigraphic classification. Stable heavy minerals clearly dominate without any incidence of volcanic constituents. These results indicate probably that the stratigraphic sequence has to be assigned to Pliocene time. The fine granulation of the sediments might additionally infer deposition at the beginning of Pliocene time, caused by climatic melioration and concomitant sea level rise which resulted in a decrease of gravel accretions. On the other hand, the existence of pudding balls does not fit to this hypothesis. Because the frequency of climate and sea-level variations increases towards Quaternary time, a correlation of the layers in this section to the Late Pliocene is more probable.

\section{Kieseloolith sequence}

Petrography and genesis: Kieseloolith layers are exposed right $\mathrm{E}$ of fault $\mathrm{F} 2$ consisting of yellow finesandy medium sand, often thinly bedded in the millimetre-range. They show erosional channels with 


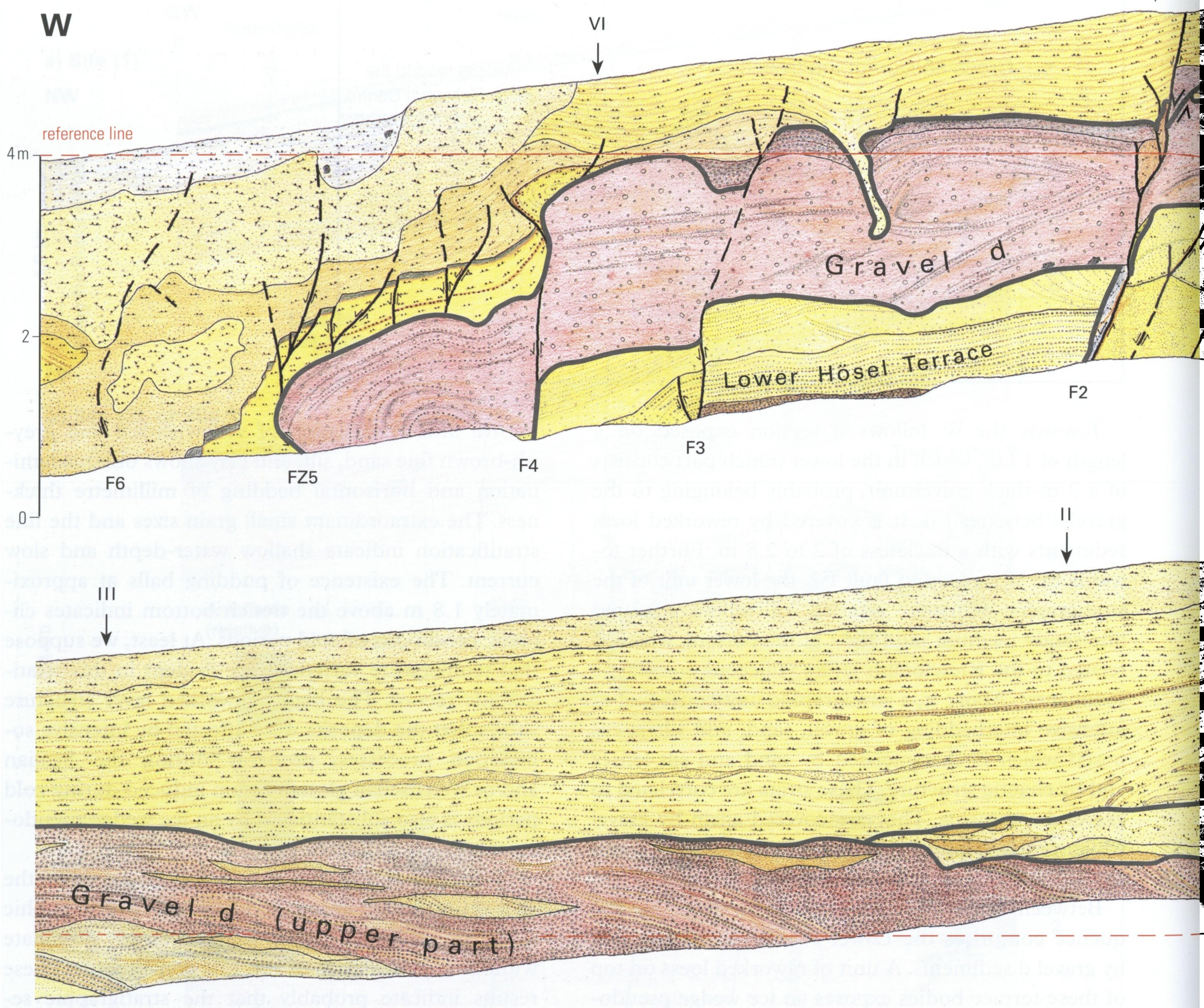

depths of a few centimetres, clay-filled at the base (Fig. 10). In most cases, the grain size decreases towards the top with the uppermost part containing clay. These sediment structures reflect a shallow, slowly flowing fluvial system. A drop stone constisting of flint was found in the upper part of the Kieseloolith layers (Fig. 11). This observation may indicate either that ice floes drifted on the fluvial system existing at that time or that the flint was transported in the roots of a tree trunk.

Stratigraphy: The fact that volcanic heavy minerals were not detected implies that these strata are older than the Younger Main Terrace deposits. Because garnet is rarely found whereas turmaline and zircon are dominating, the unit may be correlated with Pliocene sediments. The relatively low percentage of epidotite points to an assignment before the Reuverian C. As a consequence, these sediments might belong to the Kieseloolith layers in the wider sense.

\section{Lower Hösel sequence}

Petrography and genesis: The Lower Hösel layers appear right $\mathrm{W}$ of fault $\mathrm{F} 2$ at the trench floor. The lower part consists of russet and grey, clearly horizontally layered medium and fine gravel, whereas the upper portion is formed by yellow and russet medium sand. Both layering and grain size indicate a braided fluvial system typical for cold periods.

Stratigraphy: The heavy mineral spectrum is dominated by zircon, turmaline, and staurolite. The lack of 


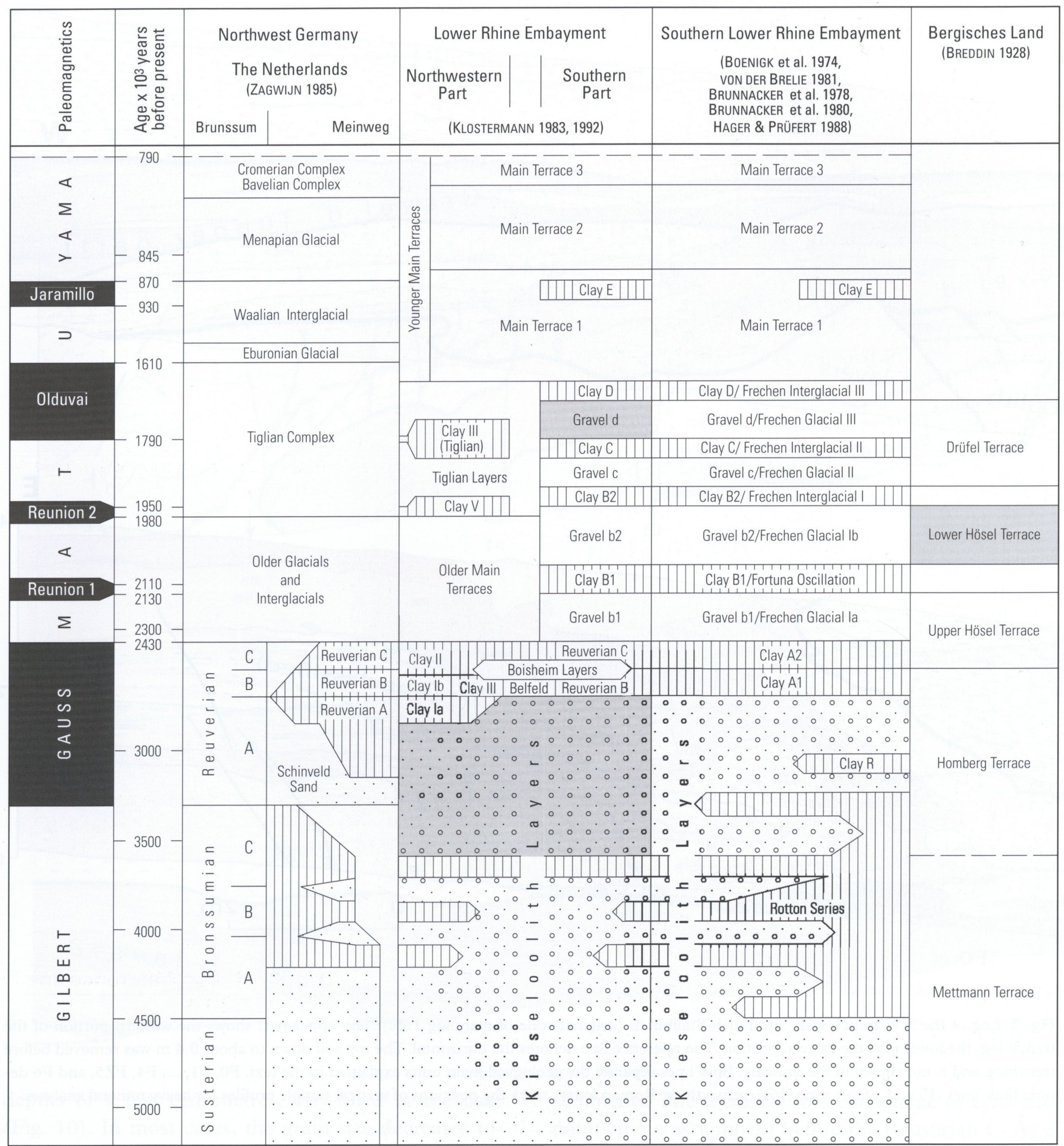

Fig. 8. Geological time chart of the Pliocene and Lower Pleistocene in the Lower Rhine Embayment area (Klostermann, 1992, 1995).

sediment structures point to a braided run-off system typical for cold periods.

Stratigraphy: There were no volcanic heavy minerals found in the spectrum, garnet is lacking completely, and the percentage of staurolite amounts up to $7 \%$. An unambiguous classification of the strata can not be given based on the heavy mineral spectrum alone. However, the great number of cold climate indicators suggests a correlation to the gravel $\mathrm{d}$ (according to Boenigk et al., 1972).

\section{Saalian / Weichselian glacial}

Petrography and genesis: The complete gravellysandy stratigraphic sequence exposed in the trench is overlain by yellowish-brown coloured silt. It is subdivided by thin clay and fine sand layers in almost all parts. This unit is formed by loess deposits which are reworked by intensive solifluction processes.

Stratigraphy: The loess was blown in probably during the Weichselian glacial. An assignment of the lower part to the Saalian glacial is regarded to be less probable. In any case, the mass transport by solifluc- 

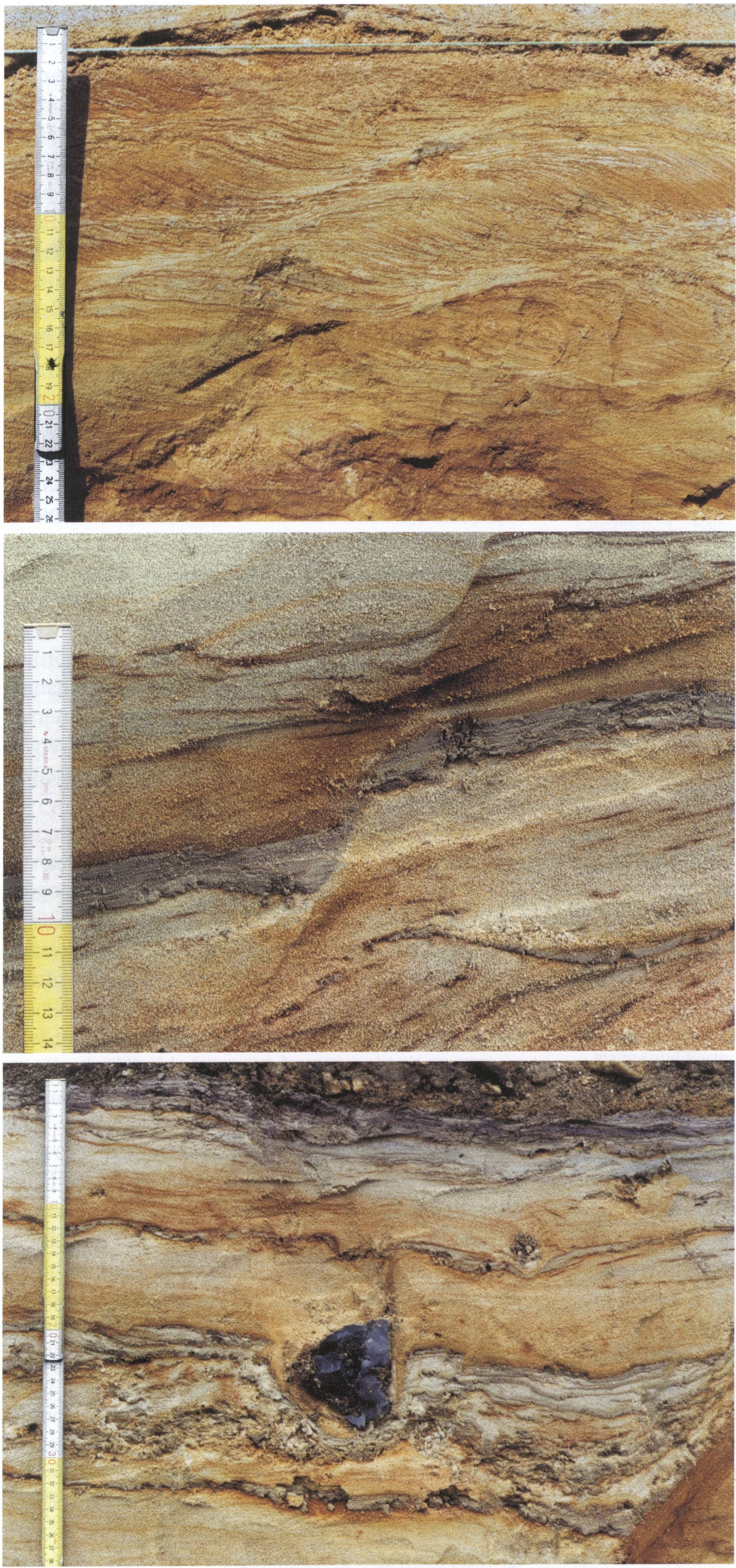

Fig. 9. Climbing ripple marks in the Pliocene layers.
Fig. 10. Stratigraphic sequence in the Kieseloolith layers.
Fig. 11. Drop-stone in the upper part of the Kieseloolith layers. 
tion should have begun during the period of deposition.

\section{Discussion}

Probably the entire tectonic system exposed in the trench is part of the Rurrand Fault implying that the eastern border of the Roer Valley Graben is, at least locally, expressed by a fault zone with a minimum width of $50 \mathrm{~m}$. The throw of the Main Terrace base (some $50 \mathrm{~m}$ ) may be interpreted as the sum of offsets at different fault traces. The highest amounts of throw are exposed at the fault zones FZ5 and at F0, which separate different geological units. This fact may indicate F0 as the footwall and FZ5 as the hanging wall enclosing the Rurrand fault zone. The minor faults in between may be not geometrically persistent along the fault line.

Because gravel d sediments overlie different geological units $\mathrm{E}$ and $\mathrm{W}$ of the fault $\mathrm{F} 2$, an episodic tectonic activity can be inferred for the Lower Pleistocene time. Because the entire gravelly-sandy stratigraphic sequence is supposed to be considerably older than about $1 \mathrm{Ma}$, the related offsets probably do not reflect the recent tectonic conditions and thus do not reveal relevant information for paleoseismological studies. The youngest fault activity is documented at the fault traces F2 (1), F4 (2), and FZ5 (3). (1) F2 reaches up to the exposed trench surface and offsets the fine sand and clay layers within the loess unit by $0.42 \mathrm{~m}$. These layers can be followed completely on both sides of F2 without any indication of unconformity. Therefore, the solifluction process affecting the entire loess stratum probably was limited in time. Considering the OSL dating results we assume that the mass transport occurred during the Weichselian glacial. Thus, the offset can be related to the last tens of ka. (2) F4 is bent towards the W indicating that the major part of the offset was produced before solifluction occurred. A younger reactivation of this fault trace is documented by a small offset of some $10 \mathrm{~cm}$ in the upper loess unit, approximately aligned to the prolongation of the initial fault dip. Related cracks were evident at the ground surface. (3) The complex system of small step-like offsets evident at FZ5 is only partly exposed and thus does not allow a detailed quantification of the amount of displacement. In the entire exposure, clear indications of coseismic fault movements, e.g. colluvial wedges, sand blows, were not exposed. Other paleoseismic features in the stratigraphic conditions and fault characteristics could not be reliably determined.

\section{Conclusions}

Based on geomorphologic analysis (s. Hinzen et al., 2001) and geological data, the target area for paleoseismological studies along the Rurrand fault was restricted to the segment reaching from Jülich to Düren. On this $13 \mathrm{~km}$-long section, detailed geophysical surveying was carried out in order to determine a site suitable for trench operation. Applying different geophysical survey techniques - (shallow) seismic reflections surveys, VES profiling, ERT and GPR sections - at five selected sites, the ground structure on fault-crossing profiles was imaged in terms of physical parameter contrasts. With seismic and VES measurements we found evidence of the Rurrand fault down to some $500 \mathrm{~m}$ and $100 \mathrm{~m}$, respectively, and could roughly determine the fault position and structure. Highly-resolved images of the near-surface ground, i. e. down to about 25 and $4 \mathrm{~m}$, respectively, were obtained from ERT and GPR profiles. It turned out that the best results in characterisation of the given local geological fault conditions were provided by the combination of ERT and GPR measurements. According to the survey results we observed small-scale changes (in the order of 1 to $10 \mathrm{~m}$ ) of the fault structure over lateral distances of 400 and $1000 \mathrm{~m}$, respectively. It was clearly evident that the fault could be exposed by trenching at the Jülich-Stallbusch site.

The tectonic structure exposed in the fault-crossing trench at this site was expressed by a complex system of faults and fault zones. The observed geological units classified according to heavy mineral analyses and OSL dating results were assigned to certain sediment ages. Offsets correlated to the deposition time of the gravel layer or to earlier periods reflect noncontinuous fault activity of older periods. Those fault traces continuing into the - probably Weichselian loess, e.g. at faults F2, F4, and FZ5, indicate fault activity since Middle or Upper Pleistocene time. This younger activity, which is supposed to be more representative for the actual tectonic regime, shows higher relevance for paleoseismological studies regarding seismic hazard assessment. However, clear indications of coseismic faulting have not been verified in the exposure. Considering the fault geometry, we suppose F2 (42 cm offset), and F4 $(10 \mathrm{~cm})$, to be most promising for future investigations.

The observed amount of subsidence $(35 \mathrm{~cm}$ at site (1) about $1 \mathrm{~km} \mathrm{NW}$ of the trench position) is similar to that of F2. Thus, shape and offset of fault F2 might indicate a correlation to the subsidence process. However, before the fault displacements can be discussed in terms of paleoearthquakes, further investigations are needed to determine the residuals of local 
subsidence. Final results on that problem will be obtained through geodetic levelling campaigns which are recently carried out by the Rheinische Braunkohlenwerke AG.

\section{Acknowledgements}

This research was carried out within the scope of the PALEOSIS project (ENV4-CT97-0578 EC Environment and Climate Research Programme). We are grateful to all the project members and colleagues for team work and discussion during the Jülich-Stallbusch trench fieldwork and analyses. We thank our associated project partner, K.-G. Hinzen (Seismological Station Bensberg), for many helpful discussions and for co-operation. We kindly appreciate the contributions of the following scientists: W. Bogdanski, E. Schimmelpfennig (VES measurements), Geophysical Section / Geological Survey of Northrhine-Westphalia - GD NRW; F. Renardy, D. Demanet, D. Leynaud et al. (seismic and ERT measurements), LGIH, Liège University; R.W. Heil et al. (seismic data processing), Deutsche Montan Technologie GmbH, Essen; C. Alteköster (GPR measurements), Section Applied Geophysics / Geological Institute, Bonn University; U. Dworschak, St. van de Logt (trench logging), Geological Department / GD NRW; U. Wefels, S. Gülsen (heavy mineral analyses), R. Stritzke (pollen analyses), Laboratory Department / GD NRW; A. Hilgers (OSL dating), Geographical Institute, Cologne University; E. Bonino (digital trench imaging), MICA, Liège University; A. Lenz (lacquer peels), Geological Department / GD NRW. Special thanks to H. Schöttler (photographs), U. Amend, J. Schardinel, E. Schümann (layout and digital compilation of figures), Cartographic Section / GD NRW. We thank P. Santanach and an anonymous colleague for careful reviews and numerous helpful comments.

\section{References}

Ahorner, L., 1962. Untersuchungen zur quartären Bruchtektonik der Niederrheinischen Bucht. Eiszeitalter und Gegenwart 13: 24-105.

Ahorner, L., 1975. Present-day stress field and seismotectonic block movements along major fault zones in central Europe. Tectonophysics 29: 233-249.

Ahorner, L., 1983. Historical seismicity and present-day microearthquake activity of the Rhenish Massif, Central Europe. In: Fuchs, K., von Gehlen, K., Mälzer, H., Murawski, H. \& Semmel, A. (eds.): Plateau Uplift. The Rhenish Shield - A Case History. Springer (Berlin), 198-221.

Alexandre, P., 1994. Historical seismicity of the lower Rhine and Meuse valleys from 600 to 1525 . A new critical review. Geologie en Mijnbouw 73: 431-438.

Boenigk, W., Kowalczyk, G. \& Brunnacker, K., 1972. Zur Geologie des Altpleistozäns der Niederrheinischen Bucht. Zeitschrift der Deutschen Geologischen Gesellschaft 123: 119-161.

Bonino, E. \& Pirard, E., 2001. A Geological information system for paleoseismological data retrieving and analysis. Cahiers du Centre Européen de Geodynamique et de Séismologie, 18: 23-25.

Cai, J., McMechan, G.A. \& Fisher, M.A., 1996. Application of ground-penetrating radar to investigation of near-surface fault properties in the San Francisco Bay region. Bulletin of the Seismological Society of America 86: 1459-1470.

Camelbeeck, T. \& Meghraoui, M., 1996. Large earthquakes in northern Europe more likely than once thought. EOS Transactions of the American Geophysical Union 77: 405, 409.

Camelbeeck, T. \& Meghraoui, M., 1998. Geological and geophysical evidence for large paleo-earthquakes with surface faulting in the Roer Graben (northwest Europe). Geophysical Journal International 132, 347-362.

Camelbeeck, T., Martin, H., Vanneste, K., Verbeek, K. \& Megraoui, M., 2001. Geomorphic evidence of active normal faulting in slow-deformation areas: the example of the Lower Rhine Embayment. Netherlands Journal of Geosciences / Geologie en Mijnbouw, this issue.

Campbell, J., Kümpel, H.-J., Fabian, M., Görres, B., Keysers, Ch.J., Kotthoff, H. \& Lehmann, K., submitted. Recent movement patterns of the Lower Rhine Basin from GPS data. Geologie en Mijnbouw / Netherlands Journal of Geosciences.

Commission of the European Communities (ed.), 2000. PALEOSIS - Evaluation of the potential for large earthquakes in regions of present day low seismicity activity in Europe. Final report, project no. ENV4-CT97-0578. Directorate-General XII for Science, Research, and Development (Brussels): 135pp.

Davis, J.L. \& Annan, A.P., 1989. Ground-penetrating radar for high-resolution mapping of soil and rock stratigraphy. Geophysical Prospecting 37: 531-551.

Demanet, D., Renardy, F., Vanneste, K., Jongmans, D., Camelbeeck, T. \& Meghraoui, M., 2001. The use of geophysical prospecting for imaging active faults in the Roer Graben, Belgium. Geophysics 66: 78-89.

Demanet, D., Evers, L.G., Teerlynck, H., Dost, B. \& Jongmans, D., 2001. Geophysical investigation along the Peel Boundary Fault (The Netherlands) for a paleoseismological study. Netherlands Journal of Geosciences / Geologie en Mijnbouw, 80, 129-138.

Forman, S.L., Pierson, J. \& Lepper, K., 1997. Luminescence geochronology. In: Sowers, J.M., Noller, J.S. \& Lettis, W.R. (eds.): Dating and Earthquakes: Reviews of Quaternary Geochronology and its Application to Paleoseismology. U.S. Nuclear Regulatory Commission (Washington): 2-259-2-287.

Forschungszentrum Jülich $\mathrm{GmbH}, 1999$. Gutachten über die Höhenbeobachtungen im Bereich des Forschungszentrums Jülich. (Jülich): unpublished.

Forschungszentrum Jülich $\mathrm{GmbH}, 2000$. Gutachten über die Höhenbeobachtungen und Höhenänderungen im Bereich des Forschungszentrums Jülich. (Jülich): unpublished.

Geluk, M.C., Duin, E.J.Th., Dusar, M., Rijkers, R.H.B., Van den Berg, M.W. \& Van Rooijen, P., 1994. Stratigraphy and tectonics of the Roer Valley Graben. Geologie en Mijnbouw 73: 129-141.

Geologisches Landesamt Nordrhein-Westfalen, 1990. Geologische Karte von Nordrhein-Westfalen 1:100,000, Blatt C5102 Mönchengladbach. (Krefeld).

Görres, B. \& Campbell, J., 1998: Bestimmung vertikaler Punktbewegungen aus GPS-Messungen, Zeitschrift für Vermessungswesen 123: 222-230.

Herbst, G., 1958. Das Alter der Bewegungen am Rurrand bei Hückelhoven. Fortschritte in der Geologie von Rheinland und Westfalen 2: 641-643.

Hinzen, K.-G., Reamer, S.K. \& Rose, Th., 2001. Geomorphologi- 
cal aspects of site selection at the Rurrand Fault for paleoseismological investigations. Netherlands Journal of Geosciences / Geologie en Mijnbouw, 80, 109-117.

Klostermann, J., 1990. Geologischer Bau - Lagerungsverhältnisse des Deckgebirges. In: Geologisches Landesamt Nordrhein-Westfalen (ed.): Geologische Karte von Nordrhein-Westfalen 1:100 000, Erläuterungen zu Blatt C5102 Mönchengladbach. (Krefeld): 34-37.

Klostermann, J., 1992. Das Quartär der Niederrheinischen Bucht. Geologisches Landesamt Nordrhein-Westfalen (Krefeld): 200pp.

Klostermann, J., 1995. Nordrhein-Westfalen. In: Benda, L. (ed.): Das Quartär Deutschlands. Gebrüder Bornträger (Berlin, Stuttgart): 59-94.

Klostermann, J., Kremers, J. \& Röder, R., 1998. Rezente tektonische Bewegungen in der Niederrheinischen Bucht. Fortschritte in der Geologie von Rheinland und Westfalen 37: 557-571.

Landesvermessungsamt Nordrhein-Westfalen (1972): Deutsche Grundkarte 1:5000. Sections Stetternich, Neulich, Daubenrath, Hambach. (Bonn).

Lehmann, K., Klostermann, J., Pelzing, R. \& Hinzen, K.-G., 2001. Paleoseismological investigations at the Rurrand Fault, FRG. Cahiers du Centre Européen de Géodynamique et de Séismologie 18: 93-96.

Loke, M.H. \& Barker, R.D., 1996. Rapid least-squares inversion of apparent resistivity pseudosections by a quasi-Newton method. Geophysical Prospecting 44: 131-152.

McCalpin, J.P., 1996. Paleoseismology. Academic Press (San Diego): $583 \mathrm{pp}$.

Meghraoui, M., Camelbeeck, T., Vanneste, K., Brondeel, M. \& Jongmans, D., 2000. Active faulting and paleoseismology along the Bree fault, lower Rhine graben, Belgium. Journal of Geophysical Research 105, (B6), 13809-13841.

Meidow, H., 1995. Rekonstruktion und Reinterpretation von historischen Erdbeben in den nördlichen Rheinlanden unter Berücksichtigung der Erfahrungen bei dem Erdbeben von Roermond am 13. April 1992. PhD thesis, Faculty of Mathematics and Natural Sciences, Cologne University: $305 \mathrm{pp}$.

Pelzing, R., 1994. Source parameter of the 1992 Roermond earthquake, the Netherlands, and some of its aftershocks recorded at the stations of the Geological Survey of Northrhine-Westphalia. Geologie en Mijnbouw 73: 215-223.

Quitzow, H.W. \& Vahlensieck, O., 1955. Über pleistozäne Gebirgsbildung und rezente Krustenbewegungen in der Niederrheini- schen Bucht. Geologische Rundschau 43: 56-67.

Rheinische Braunkohlenwerke AG, 1987. Diverse borehole sections. (Cologne, unpublished).

Rheinische Braunkohlenwerke AG, 2000. Personal communication. (Cologne).

Sieberg, A., 1940. Beiträge zum Erdbebenkatalog Deutschlands und der angrenzenden Gebiete für die Jahre 58 bis 1799. Mitteilungen des Deutschen Reichs-Erdbebendienstes, Heft 2 (Berlin): $112 \mathrm{pp}$.

Sponheuer, W., 1952. Erdbebenkatalog Deutschlands und der angrenzenden Gebiete für die Jahre 1800 bis 1899. Mitteilungen des Deutschen Erdbebendienstes, Heft 3 (Berlin): 185 pp.

Van den Berg, M.W., 1994. Neotectonics of the Roer Valley rift system. Style and rate of crustal deformation inferred from syn-tectonic sedimentation. Geologie en Mijnbouw 73: 143-156.

Van den Berg, M.W., Groenewoud, W., Lorenz, G.K., Lubbers, P.J., Brus, D.J. \& Kroonenberg, S.B., 1994. Patterns and velocity of recent crustal movements in the Dutch part of the Roer Valley rift system. Geologie en Mijnbouw 73: 157-167.

Van den Berg, M.W., Vanneste, K., Dost, B., Lokhorst, A., Van Eijck, M. \& Verbeeck, K., 2001. Paleoseismic investigation along the Peel Boundary Fault: geological setting, site selection and trenching results. Netherlands Journal of Geosciences / Geologie en Mijnbouw, 81, 1, 2002.

Vandenberghe, J., 1982. Geoelectric investigations of a fault system in Quaternary deposits. Geophysical Prospecting 30: 879-897.

Vanneste, K., Meghraoui, M. \& Camelbeeck, T., 1999. Late Quaternary earthquake-related soft-sediment deformation along the Belgian portion of the Feldbiss Fault, Lower Rhine Graben system. Tectonophysics 309, 57-79.

Vanneste, K. \& Verbeeck, K., 2001. Paleoseismological analysis of the Rurrand Fault near Jülich, Roer Valley graben, Germany: Coseismic or aseismic faulting history? Netherlands Journal of Geosciences / Geologie en Mijnbouw, 80, 155-169.

Wrede, V. \& Hilden, H.D., 1988. Geologische Entwicklung. In: Geologisches Landesamt Nordrhein-Westfalen (ed.): Geologie am Niederrhein. (Krefeld): 7-14.

Ziegler, P.A., 1994. Cenozoic rift system of western and central Europe: an overview. Geologie en Mijnbouw 73: 99-127.

Zijerveld, L., Stephenson, R., Cloetingh, S., Duin, E. \& Van den Berg, M.W., 1992. Subsidence analysis and modelling of the Roer Valley Graben (SE Netherlands). Tectonophysics 208: 159171. 